\title{
PHYLLOCHRON OF Paspalum notatum FL. AND Coelorhachis selloana (HACK.) CAMUS IN NATURAL PASTURE
}

\author{
Lilian Eggers*; Mónica Cadenazzi²; Ilsi Iob Boldrini ${ }^{3}$ \\ ${ }^{1}$ PUCRS - Dept. de Biologia - C.P. 1429 - 90619-900 - Porto Alegre, RS - Brazil. \\ ${ }^{2} U D E L A R / E E M A C$ - Dept. de Estatística. Ruta 3, km 363 - C.P. 60000 - Paysandu - Uruguay. \\ ${ }^{3}$ UFRGS - Dept. de Botânica, Av. Bento Gonçalves, 9500, prédio 43433, Campus do Vale - 91501-970 - Porto \\ Alegre, $R S$ - Brazil. \\ *Corresponding author <leggers@pucrs.br>
}

\begin{abstract}
Leaf appearance rate and phyllochron are related variables which play a central role in forage production. Phyllochron is the time interval between the appearance of successive leaves and varies according to a number of environmental factors, among which temperature is the most important. The experiment was conducted in natural pasture with the aim of testing phyllochron variation under different seasons, herbage allowances, and topographic positions. Marked tillers were used to define the phyllochron, establishing a relationship between the number of leaves produced against thermal time during the sampling period. The time (expressed in ${ }^{\circ} \mathrm{C}$ ) needed for the emergence of a leaf is equal to $1 / \mathrm{b}$, where $b$ is the slope coefficient of the regression. The lines for the season combinations, herbage allowances and topographic positions sampled were compared. Under Spring and Summer conditions, the phyllochrons for P. notatum and C. selloana were $156^{\circ} \mathrm{C}$ and $238^{\circ} \mathrm{C}$ respectively, regardless of treatment.

Key words: morphogenesis, leaf appearance, native grassland

\section{FILOCRONO DE Paspalum notatum FL. E Coelorhachis selloana (HACK.) CAMUS EM PASTAGEM NATURAL}

\begin{abstract}
RESUMO: A taxa de aparecimento de folhas (TAF) e o filocrono são conceitos associados, que exercem forte influência na produção de forragem. O filocrono é o intervalo de tempo entre o aparecimento de duas folhas sucessivas acima do pseudocaule e varia de acordo com alguns fatores ambientais, sendo a temperatura o fator determinante. O experimento foi conduzido em pastagem natural em Eldorado do Sul, RS, com o objetivo de testar a variação no filocrono em diferentes estações do ano, níveis de oferta de forragem (NOF) e posições topográficas (PT). Para a definição do filocrono, foram amostrados perfilhos marcados e estabeleceuse a relação entre número de folhas produzidas e a soma térmica do período amostral. A soma térmica (em ${ }^{\circ} \mathrm{C}$ ) necessária para que a planta emita uma folha é igual a 1/b, sendo b o coeficiente angular verificado na regressão. As retas obtidas para as combinações entre estações, NOF e PT foram comparadas. Em condições de primavera e verão, se obteve filocrono de $156^{\circ} \mathrm{C}$ para $P$. notatum e de $238^{\circ} \mathrm{C}$ para C. selloana, independentemente dos tratamentos avaliados.

Palavras-chave: morfogênese, aparecimento de folhas, pastagem nativa
\end{abstract}

\section{INTRODUCTION}

Natural pastures predominate in South Brazil but little is known about morphogenesis of the native species in relation to environmental conditions and grazing pressure. Phyllochron is a morphogenetic characteristic defined as the time interval between the appearance of two successive leaves (Skinner \& Nelson, 1995) and it is considered constant when measured as thermal time. In association with other morphogenetic characteristics, it determines the structure of a pasture and its leaf area index (LAI) (Chapman \& Lemaire, 1993). Morphogenesis allows the successional dynamics of multispecies pastures to be understood. Through the knowledge of leaf emission rhythm (phyllochron) and characteristics such as ex- tension rate and the rhythm of tillering for different species, associated with the variation in intake (defoliation), it is possible to explain dominance or disappearance of certain species from the community and, consequently, its botanical composition. Phyllochron can be applied in the establishment of mathematical models that can be used by extensionists and producers to determine management practices such as cutting, grazing or application of fertilizers and pesticides (Frank \& Bauer, 1989; Wilhem \& McMaster, 1995).

The present work tested the hypothesis that there is homogeneity in phyllochron of Paspalum notatum and Coelorhachis selloana plants, sampled in natural pasture, when submitted to factors such as seasons of the year (growth seasons), herbage allowances and topographic 
positions. Evaluation in different seasons attempt to verify the constancy of phyllochron expressed as thermal time. Evaluation under different topographic positions and herbage allowances tested the influence of soil type and moisture and the effect of grazing intensity, respectively.

Temperature is decisive in phyllochron variation (Chapman \& Lemaire, 1993). The constant response of phyllochron expressed as thermal time indicates a standard, genetically-determined response by the plant, which should be managed through chronological time according to meteorological variations. Other aspects, such as water and nutrient availability (especially $\mathrm{N}$ ) at non-extreme levels, as well as carbohydrate reserves, concentration of salts and $\mathrm{CO}_{2}$, and amount and quality of light, have little influence on phyllochron (Frank \& Bauer, 1995; Wilhem \& McMaster, 1995). Under herbage allowances and defoliation treatments, phyllochron shows variable behavior, responding either as a constant (Frank \& Hofmann, 1989) or showing variation (Agnusdei et al., 1994; 1996).

\section{MATERIAL AND METHODS}

The experiment was conducted in Eldorado do Sul, RS ( $\left.30^{\circ} 05^{\prime} \mathrm{S}, 51^{\circ} 40^{\prime} \mathrm{W}\right)$, with a Cfa climate, according to Köppen's classification. Three natural pasture paddocks were sampled under continuous grazing, submitted to herbage allowances (HA) of $4.0,8.0$, and $12.0 \mathrm{~kg}$ dry matter $(\mathrm{DM}) / 100 \mathrm{~kg}$ live weight $(\mathrm{LW}) /$ day, corresponding to the mean values of $510 ; 1,030$; and $1,480 \mathrm{~kg}$ $\mathrm{DM} \mathrm{ha}^{-1}$ of residual herbage mass (Maraschin, 1998), in treatments maintained since the Spring of 1987. Considering the topographic variations present in the paddocks, which in turn reflect differences in soil type and moisture, hilltop (Ht) and pediment (Pe) topographic positions (TP) were sampled. The sampling periods were concentrated in the 1996/97 and 1997/98 growing seasons. Treatments were arranged in a factorial scheme (3 HA and 2 $\mathrm{TP}$ ) in a completely randomized design, analyzed for each season.

To calculate phyllochron, marked tillers were sampled, allowing frequent observations of the same individual units (Hodgson, 1966; Davies, 1993; Grant \& Marriott, 1994). Plant growth was monitored during periods of 19 days, with visits to tillers every two or three days.

Tillers of both species were observed during different periods within the same season. $P$. notatum tillers were studied at all three HA, while C. selloana was evaluated only at HA 8.0 and $12.0 \%$ LW. Tillers were marked at the lower stratum of the pasture, arranged along $3 \mathrm{~m}$ transects. Five transects were marked and six tillers spaced $20 \mathrm{~cm}$ apart were sampled per transect, resulting in 30 tillers per $\mathrm{HA} \times \mathrm{PT}$ combination.
The lack of knowledge about the basal growing temperature for the studied species prevented the characterization of phyllochron in degree-days (GDD). Therefore the daily temperatures were considered within the range comprised between the basal temperatures for most periods sampled, and thermal time (TT) was calculated for the days under evaluation. TT is the summation of mean daily temperatures, calculated by the arithmetic mean between maximum and minimum daily temperatures, according to the formula: $\mathrm{TT}=\Sigma\left[\left(\mathrm{T}_{\max }+\mathrm{T}_{\min }\right) / 2\right]$ (Ometto, 1981).

Phyllochron was determined for each HA $\times$ TP combination by the linear regression between the number of leaves produced and the thermal time in each sampled period. The thermal time $\left({ }^{\circ} \mathrm{C}\right)$ necessary for the appearance of a leaf is equal to $1 / b$, where $b$ is the slope coefficient of the regression. The homogeneity of the coefficients among $\mathrm{HA} \times \mathrm{PT}$ combinations was tested using the analysis of covariance model. This analysis was performed in two steps: first, the homogeneity of the coefficients of regression between the number of leaves produced and the thermal time within each season was considered, using the $\mathrm{HA} \times \mathrm{TP}$ treatments as covariables. Later, the homogeneity of coefficients was tested using seasons as covariables. The analysis of covariance model used was:

$$
y_{i j}=\alpha+\left(\alpha_{i}-\alpha\right)+\beta x_{i j}+\left(\beta_{i}-\beta\right) x_{i j}+\varepsilon_{i j}
$$

where: $y_{i j}$ - observed values of leaves produced; $x_{i j}$ - observed values of thermal time; $\alpha$ - mean intercept; $\alpha_{i}$ - intercept of the $\mathrm{i}^{\text {th }}$ treatment or season; $\beta$ - effect of the mean coefficient of regression; $\beta_{i}$ - coefficient of regression of the $\mathrm{i}^{\text {th }}$ treatment or season; $\varepsilon_{i j}$ - random effect of the experimental error.

The analysis was performed using the mixed procedure of SAS application (SAS, 1996). Finally, using homogeneous data set for each species, a single equation was fitted to determine the phyllochron.

During sampling, meteorological variables were monitored and water balance was calculated at 10-day intervals, according to Thornthwaite-Mather. The survey for soil moisture determination was carried out in three occasions (Summer/97; Spring/97; and Summer/98), to characterize the soil moisture in the treatments and to verify the influence of drought periods that occurred during sampling. These data are fully described in Eggers (1999), and will be mentioned here whenever they played a crucial role over the results.

\section{RESULTS AND DISCUSSION}

\section{Paspalum notatum}

The phyllochron of $P$. notatum indicated a trend for greater leaf appearance rate (LAR) in the Spring and Summer of 1996/97 (Table 1). The comparison among the 
Table 1 - Paspalum notatum phyllochron, expressed as thermal time/leaf $\left({ }^{\circ} \mathrm{C}\right)$, for the combinations of herbage allowances (HA 4.0, 8.0, and $12.0 \mathrm{~kg} \mathrm{DM} / 100 \mathrm{~kg} \mathrm{LW/day)} \mathrm{and} \mathrm{topographic} \mathrm{positions} \mathrm{-} \mathrm{TP} \mathrm{(Hilltop} \mathrm{-} \mathrm{Ht;} \mathrm{Pediment} \mathrm{-} \mathrm{Pe),} \mathrm{and} \mathrm{for}$ all treatments (general) in the seasons of the year (SPG - Spring; SMR - Summer; FALL - Fall), 1996/98.

\begin{tabular}{llllcccc}
\hline & \multicolumn{7}{c}{$\mathrm{HA} \times \mathrm{TP}$} \\
\cline { 2 - 6 } Season & $4 \mathrm{Ht}$ & $4 \mathrm{Pe}$ & $8 \mathrm{Ht}$ & $8 \mathrm{Pe}$ & $12 \mathrm{Ht}$ & $12 \mathrm{Pe}$ & general \\
\hline SPG/96 & 154 & 132 & 156 & 149 & 143 & 192 & 152 \\
SMR/97 & 169 & 164 & 159 & 172 & 154 & 169 & 164 \\
FALL/97 & $345 \mathrm{~b}$ & $222 \mathrm{c}$ & $357 \mathrm{~b}$ & $435 \mathrm{ab}$ & $333 \mathrm{~b}$ & $667 \mathrm{a}$ & 345 \\
SPG/97 & 164 & 200 & 189 & 217 & 161 & 175 & $183 \mathrm{c}$ \\
SMR/98 & $159 \mathrm{bc}$ & $154 \mathrm{bc}$ & $200 \mathrm{a}$ & $170 \mathrm{abc}$ & $179 \mathrm{ab}$ & 167 \\
\hline
\end{tabular}

For Fall/97 and Summer/98, values followed by a common letter do not differ with regard to the coefficients of the analyzed lines (ANCOVA, $P<0.05$ ).

regressions of the $\mathrm{HA} \times \mathrm{TP}$ combinations for each season showed no difference in phyllochron in the Spring/ 96, Summer/97 and Spring/97.

In the Summer/98, the trend line indicated a phyllochron of $167^{\circ} \mathrm{C}$ with a coefficient of determination $\left(R^{2}\right)$ of $94 \%$. However, treatments differed between extremes of a smaller phyllochron in $12.0 \% \mathrm{LW}$, pediment treatment and a greater one in $8.0 \% \mathrm{LW}$, hilltop treatment. It is believed that the variation between treatments found for that season resulted from a reduction in the precipitation that occurred in the last two weeks of sampling. Under such conditions, growth response could be different because of the variation in soil moisture content and phyllochron reduction was actually proportional to this variation, corresponding to maximum soil moisture content in $12.0 \% \mathrm{HA}$, pediment treatment (14.2\%), and minimum in $8.0 \%$ HA, hilltop treatment $(9.86 \%)$ (Eggers, 1999).

In the Fall/97, two factors seemed to have influenced phyllochron increase: the decrease in daily mean temperatures and water deficit period preceeding sampling (Eggers, 1999). Regarding temperature, Summer species such as those belonging to Paspalum need higher temperatures for growth and development and, although the optimum temperature for $P$. notatum is unknown, it seems that the sampled period (May/97) showed temperatures lower than optimum (mean monthly temperature $15.2^{\circ} \mathrm{C}$ ). Mitchell \& Lucanus, quoted by Anslow (1966), investigated the response of different species to temperature regimes and defined the optimum temperatures for leaf appearance in Paspalum dilatatum $\left(29-35^{\circ} \mathrm{C}\right)$, Lolium perenne $\left(18-29^{\circ} \mathrm{C}\right)$, Agrostis tenuis $\left(18-29^{\circ} \mathrm{C}\right)$ and Dactylis glomerata $\left(18^{\circ} \mathrm{C}\right)$.

The homogeneity among treatments in the Spring/ 96, Summer/97 and Spring/97 seasons, and the relationship among differences and environment conditions in the Fall/97 and Summer/98 indicated that phyllochron is independent from the HA $\times$ TP combinations, what agrees with results reported by Frank \& Hofmann (1989), who did not find phyllochron differences among five species submitted to two grazing intensities. On the other hand, Agnusdei et al. (1994; 1996) observed differences in the phyllochron of species subjected to defoliation or under grazing exclusion conditions, and called the attention to the fact that species varies in response. The study on four grasses showed that Paspalum dilatatum, differently from Cynodon dactylon, Leersia hexandra and Festuca arundinacea, did not vary in LAR under three grazing conditions (light, moderate, and intense) (Agnusdei et al., 1997).

The similarity between phyllochron in the Spring of 96 and 97 and in the Summer of 97 and 98 (Table 1) allowed the fitness of a general equation for this set of data $\left(\mathrm{R}^{2}=93 \%\right.$; $\left.\mathrm{CV}=14 \%\right)$, defining a phyllochron of $156^{\circ} \mathrm{C}$ for $P$. notatum under mild (non-hibernal) temperature conditions and favorable precipitation (no water deficit) (Figure 1). Figure 1 shows the number of leaves produced in all seasons, including Fall/97 and, separately for that, the $4.0 \% \mathrm{LW}$, pediment treatment, with similar values observed for all other seasons. The proximity of the $4.0 \% \mathrm{HA}$, pediment treatment values in relation to those obtained in the Spring/96, Summer/97 and Spring /97, results from a higher moisture condition in such $\mathrm{HA} \times$ TP combination, even though specific soil moisture content data are not available for that period.

\section{Coelorhachis selloana}

The trend lines for the Spring/96, Summer/97 and Summer/98 indicated that $C$. selloana phyllochron was not different in the HA $\times$ PT combinations (Table 2). In the Spring/97, phyllochron observed in the $8.0 \% \mathrm{LW}$, pediment treatment was smaller than those verified for the hilltop (8.0 and $12.0 \% \mathrm{LW}$ ). The reason for this is not supported by meteorological or soil moisture conditions, and are, therefore, unknown.

In the Summer/97, no differences were verified among HA $\times$ TP combinations. However, general phyllochron was $417^{\circ} \mathrm{C}$ (Table 2), which may be considered very high. It is believed that this could be a consequence of soil water deficit from March to May 97 


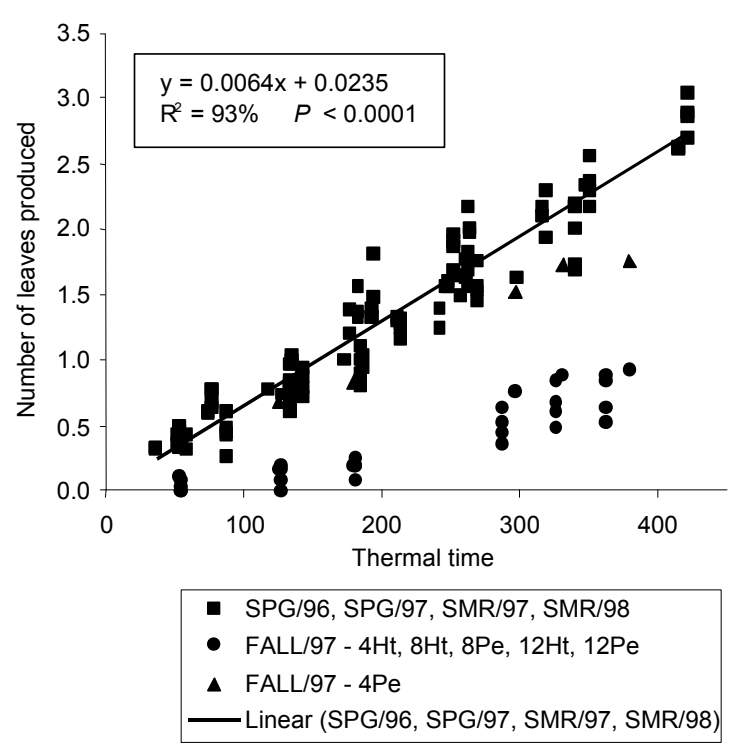

Figure 1 - Relationship between leaf appearance and accumulated thermal time $\left({ }^{\circ} \mathrm{C}\right)$ for Paspalum notatum in the Spring of 96 and 97, Summer of 97 and 98 and Fall of 97.

Table 2 - Coelorhachis selloana phyllochron, expressed as thermal time/leaf $\left({ }^{\circ} \mathrm{C}\right)$, for the combinations of herbage allowances (HA 8.0 and $12.0 \mathrm{~kg} \mathrm{DM} / 100$ $\mathrm{kg} \mathrm{LW/day)} \mathrm{and} \mathrm{topographic} \mathrm{positions} \mathrm{(Hilltop} \mathrm{-}$ $\mathrm{Ht}$; Pediment - Pe), and for all treatments (general) in the seasons of the year (SPR - Spring; SMR Summer), 1996/98.

\begin{tabular}{llllll}
\hline & \multicolumn{5}{c}{$\mathrm{HA} \times \mathrm{TP}$} \\
\cline { 2 - 5 } Season & $8 \mathrm{Ht}$ & $8 \mathrm{Pe}$ & $12 \mathrm{Ht}$ & $12 \mathrm{Pe}$ & general \\
\hline SPG/96 & 217 & 250 & 222 & 250 & 233 \\
SMR/97 & 500 & 417 & 526 & 312 & 417 \\
SPG/97 & $238 \mathrm{a}$ & $185 \mathrm{~b}$ & $263 \mathrm{a}$ & $227 \mathrm{ab}$ & 227 \\
SMR/98 & 294 & 233 & 250 & 250 & 256 \\
\hline
\end{tabular}

For Spring/97, values followed by a common letter do not differ with regard to the coefficients of the analyzed lines (ANCOVA, $P<0.05)$.

(Eggers, 1999). Phyllochron increase was also observed by Morales et al. (1997) in Lotus corniculatus as soil water availability decreased. The phyllochron for this species was $83^{\circ} \mathrm{C}$ at $100 \%$ of the field capacity, increasing to $93^{\circ} \mathrm{C}$ at $70 \%$ and to $110^{\circ} \mathrm{C}$ at $50 \%$ of the field capacity. As a result of the high phyllochron value showed by C. selloana in the Summer/97, and the water deficit, those data were discarded for the calculation of the general equation of the phyllochron. Only data from Spring/96, Spring/97 and Summer/98 were used in the regression $\left(\mathrm{R}^{2}\right.$ $=93 \% ; \mathrm{CV}=13 \%$ ), and the phyllochron obtained was $238^{\circ} \mathrm{C}$ (Figure 2). The effect of water deficit on the appearance of new leaves for this species can be observed in Figure 2 (Summer/97).

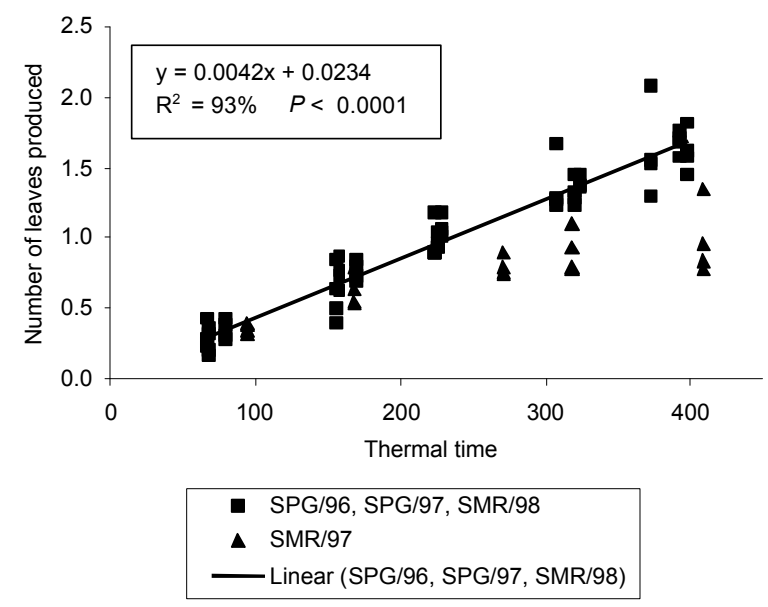

Figure 2 - Relationship between leaf appearance and accumulated thermal time $\left({ }^{\circ} \mathrm{C}\right)$ for Coelorhachis selloana in the Spring of 96 and 97, and Summer of 97 and 98.

Phyllochron in grasses are species-specific and quite variable. In Winter species, such as Lolium perenne and Festuca arundinacea, intervals of 110 growing degreedays (GDD) and 230 GDD were observed, respectively, between the appearance of two successive leaves (Davies \& Thomas, 1983; Lemaire, 1985, quoted by Lemaire \& Chapman, 1996). In a greenhouse experiment, a population of Bromus auleticus was studied by Soares et al. (1998) and showed phyllochron ranging between 345 and 417 GDD. Briza subaristata and Piptochaetium montevidense were studied by Denardin (2001), who observed smaller phyllochron in colder periods for both species. According to this author, Briza subaristata showed a phyllochron of $244^{\circ} \mathrm{C}$ in the Fall and $586^{\circ} \mathrm{C}$ in the Summer and, finally, Piptochaetium montevidense showed phyllochrons of $320^{\circ} \mathrm{C}$ and $555^{\circ} \mathrm{C}$ in the Fall and Summer, respectively.

In Summer grasses, the smallest value of phyllochron (84 GD) was recorded for Pennisetum purpureum cv. Mott (Almeida et al., 1997). In natural pastures, Andropogon lateralis is considered a species with slow emission of leaves, showing thermal time of $392^{\circ} \mathrm{C}$ for the interval of appearance between two leaves (Cruz, 1998). For the same species, Quadros (1999) obtained a phyllochron of approximately 200 GDD and suggested that the difference with regard to Cruz (1998) was related to a greater nutrient availability in field burning and grazing exclusion treatments studied by him. The $P$. notatum $\left(156^{\circ} \mathrm{C}\right)$ and $C$. selloana $\left(238^{\circ} \mathrm{C}\right)$ phyllochrons lie between the verified for Pennisetum purpureum and Andropogon lateralis (according to Cruz, 1998). The low phyllochron expressed by $P$. notatum under natural conditions could be considered an indicator of the adaptive advantage of this species in natural fields of the Brazilian state of Rio Grande do Sul, since it represents a species with a high leaf appearance rate. In addition, the prostrate habit and the storage rhizome of this species are favorable in the case of stressful conditions. 
The determination of phyllochron and the understanding of the influence of environment and management conditions allow a closer observation and analysis of the population dynamics of species of interest in the field. Constancy in phyllochron, based on the evaluation of species in different periods, HA and TP, highlights the crucial role of temperature in the process of formation of new leaves. In addition, a strong influence of water availability was observed. Water availability plays an essential role in cell extension (Schnyder \& Nelson, 1988; Skinner \& Nelson, 1995) and its decrease reduces extension rate, resulting in longer intervals between the appearance of successive leaves. In this work, a greater phyllochron was observed during periods of water deficit and these observations are consistent with the data of Denardin (2001) who considered that the most limiting factor for vegetative growth in the Summer could be soil water availability rather than high temperatures.

\section{CONCLUSIONS}

The phyllochron of Paspalum notatum and Coelorhachis selloana did not show differences as a result of the herbage allowances sampled. Differences observed were related to soil moisture conditions in the sampling periods which, together with temperature, are essential aspects influencing phyllochron. In Spring and Summer, considering the absence of water deficit, a constant phyllochron was obtained for each species. Such values find potential application for the validation of prediction models for the structure of a pasture, according to the model proposed by Chapman \& Lemaire (1993), and can be used to better define the most suitable moment for the use of management practices.

\section{ACKNOWLEDGEMENTS}

To Prof. Dr. Carlos Nabinger for his valuable suggestions and to CAPES for scholarship granted to the first author.

\section{REFERENCES}

AGNUSDEI, M.G.; COLABELLI, M.; MAZZANTI, A. Crecimiento y morfogenesis de especies nativas y naturalizadas de la Pampa deprimida bonaerense. Revista Argentina de Producción Animal, v.14, p.61-62, 1994.

AGNUSDEI, M.G.; COLABELLI, M.; MAZZANTI, A. Morfogenesis de especies nativas y naturalizadas de la Pampa deprimida (Argentina). Revista Argentina de Producción Animal, v.16, p.245-246, 1996.

AGNUSDEI, M.G.; MAZZANTI, A.; CORDERO, J.; WADE, M.H. Leaf appearance rate of native and introduced grasses under different intensities of continuous grazing (Argentina). In: INTERNATIONAL GRASSLAND CONGRESS, 18., Winnipeg, Saskatoon, 1997. Proceedings. Winnipeg: International Grassland Congress Association, 1997. Session 29, p.13-14.
ALMEIDA, E.X. de; SETELICH, E.A.; MARASCHIN, G.E. Oferta de forragem e variáveis morfogênicas em capim elefante anão cv. Mott. In: REUNIÃO ANUAL DA SOCIEDADE BRASILEIRA DE ZOOTECNIA, 34., Juiz de Fora, 1997. Anais. Juiz de Fora: SBZ, 1997. p.240-242.

ANSLOW, R.C. The rate of appearance of leaves on tillers of the Gramineae. Herbage Abstracts, v.36, p.149-155, 1966.

CHAPMAN, D.F.; LEMAIRE, G. Morphogenetic and structural determinants of plant regrowth after defoliation. In: INTERNATIONAL GRASSLAND CONGRESS, 17., Palmerston North, 1993. Proceedings. Palmerston North: New Zealand Grassland Association; Keeling \& Mundi, 1993. p.95-104.

CRUZ, F.P. da. Dinâmica de crescimento, desenvolvimento e desfolhação em Andropogon lateralis Nees. Porto Alegre: UFRGS, 1998. 106p. (Dissertação - Mestrado).

DAVIES, A. Tissue turnover in the sward. In: DAVIES, A.; BAKER, R.D.; GRANT, S.A.; LAIDLAW, A.S. (Ed.) Sward measurement handbook. London: British Grassland Society, 1993. cap.9, p.183-216.

DENARDIN, R.B.N. Avaliações morfogênicas e agronômicas de Piptochaetium montevidense (Spreng.) Parodi e Briza subaristata Lam. Porto Alegre: UFRGS, 2001. 218p. (Tese - Doutorado).

EGGERS, L. Morfogênese e desfolhação de Paspalum notatum Fl. e Coelorhachis selloana (Hack.) Camus em níveis de oferta de forragem. Porto Alegre: UFRGS, 1999. 148p. (Tese - Doutorado).

FRANK, A.B.; HOFMANN, L. Relationship among grazing management, growing degree-days, and morphological development for native grasses on the Northern Great Plains. Journal of Range Management, v.42, p.199-202, 1989.

FRANK, A.B.; BAUER, A. Phyllochron differences in wheat, barley, and forage grasses. Crop Science, v.35, p.19-23, 1995.

GRANT, S.A.; MARRIOTT, C.A. Detailed studies of grazed swards techniques and conclusions. Journal of Agricultural Science, v.122, p.1-6, 1994.

HODGSON, J. The frequency of defoliation of individual tillers in a setstocked sward. Journal of the British Grassland Society, v.21, p.258263, 1966.

LEMAIRE, G.; CHAPMAN, D. Tissue flows in grazed plant communities. In: HODGSON, J.; ILLIUS, A.W. (Ed.) The ecology and management of grazing systems. Wallingford: CBA International, 1996. cap.1, p.3-36.

MARASCHIN, G.E. Manejo de pastagens nativas, produtividade animal e dinâmica da vegetação em pastagens nativas do Rio Grande do Sul. In: REUNIÃO DO GRUPO TÉCNICO DO CONE SUL - ZONA CAMPOS, 17., Lages, 1998. Anais. Lages: EPAGRI; UDESC, 1998. p.47-54.

MORALES, A.S. de; NABINGER, C.; ROSA, L.M.; MARASCHIN, G.E. Efeito da limitação hídrica sobre a morfogênese e repartição da biomassa de Lotus corniculatus L. cv São Gabriel. In: REUNIÃO ANUAL DA SOCIEDADE BRASILEIRA DE ZOOTECNIA, 34., Juiz de Fora, 1997. Anais. Juiz de Fora: SBZ, 1997. p.124-126.

OMETTO, J.C. Bioclimatologia vegetal. São Paulo: CERES, 1981. 440p.

QUADROS, F.L.P. de Dinâmica vegetacional em pastagem natural submetida a tratamentos de queima e pastejo. Porto Alegre: UFRGS, 1999. 109p. (Tese - Doutorado).

SAS INSTITUTE. SAS/STAT: User's guide. Cary: SAS Institute, 1996. 633p.

SCHNYDER, H.; NELSON, C. J. Diurnal growth of tall fescue leaf blades. I. Spatial distribution of growth, deposition of water, and assimilate import in the elongation zone. Plant Physiology, v.86, p.1070-1076, 1988.

SKINNER, R.H.; NELSON, C.J. Elongation of the grass leaf and its relationship to the phyllochron. Crop Science, v.35, p.4-10, 1995.

SOARES, G.C.; DALL'AGNOL, M.; NABINGER, C.; COSTA, J.Q.F.F.; TONELOTTO, L.A.. Estudo da morfogênese em uma população de Bromus auleticus Trin. In: REUNIÃO DO GRUPO TÉCNICO DO CONE SUL - ZONA CAMPOS, 17., Lages, 1998. Anais. Lages: EPAGRI; UDESC, 1998. p.101.

WILHELM, W.W.; McMASTER, G.S. Importance of the phyllochron in studying development and growth in grasses. Crop Science, v.35, p.13, 1995.

Received December 13, 2002

Accepted May 15, 2004 